\title{
RESULTS FROM SIMULATED CONTACT-HANDLED TRANSURANIC WASTE EXPERIMENTS AT THE WASTE ISOLATION PILO'T PLANT
}

\author{
MARTIN A. MOLECKE, N. ROB SORENSEN, AND JAMES L. KRUMHANSL
} Sandia National Laboratories, Albuquerque, NM 87185-1341

\begin{abstract}
We conducted in situ experiments with simulated, i.e., nonradioactive, contact-handled transuranic (CH TRU) waste drums at the Waste Isolation Pilot Plant (WIPP) facility for a period of about four years. We performed these tests in two rooms in rock salt, at WIPP, with drums surrounded by crushed salt or $70 \mathrm{wt} . \%$ salt $/ 30 \mathrm{wt}$. $\%$ bentonite clay backfills, or partially submerged in a $\mathrm{NaCl}$ brine pool. Air and brine temperatures were maintained at $\sim 40^{\circ} \mathrm{C}$. These full-scale (210-L drum) experiments provided in situ data on: backfill material moisture-sorption and physical properties in the presence of brine; waste container corrosion adequacy; and, migration of chemical tracers (nonradioactive actinide and fission product simulants) in the near-field vicinity, all as a function of time. Individual drums, backfill, and brine samples were removed periodically for laboratory evaluations. Waste container testing in the presence of brine and brine-moistened backfill materials served as a severe overtest of long-term conditions that could be anticipated in an actual salt waste repository. We also obtained relevant operational-test emplacement and retrieval experience. All test results are intended to support both the acceptance of actual TRU wastes at the WIPP and performance assessment data needs. We provide an overview and technical data summary focusing on the WIPP CH TRU environmental overtests involving 174 waste drums in the presence of backfill materials and the brine pool, with posttest laboratory materials analyses of backfill sorbed-moisture content, CH TRU drum corrosion, tracer migration, and associated test observations.
\end{abstract}

\section{INTRODUCTION}

The Waste Isolation Pilot Plant, WIPP, is a U.S. Department of Energy mined, geologic repository intended to demonstrate the safe, long-term isolation of defense-related, transuranic wastes. It is located in southeastern New Mexico, about $650 \mathrm{~m}$ underground in the Salado Formation, a thick bedded salt (halite) layer. We have conducted in situ emplacement and multiyear testing of simulated, nonradioactive contact-handled transuranic (CH TRU) waste drums and several backfill materials in the WIPP. These simulated CH TRU waste experiments were an important segment of the Sandia National Laboratories-WIPP Waste Package Performance program.' This program included the direction and performance of all materials-related and associated technical operations-related, in situ testing on both simulated $\mathrm{CH}$ and remote-handled (RH) TRU waste containers and emplacements. ${ }^{1,2}$ Results from the parallel WIPP RH TRU tests were reported previously. ${ }^{3}$ The predominant gnais of the $\mathrm{CH}$ TRU segment of this test program were to provide: comprehensive in situ and supporting laboratory data bases for waste container corrosion and adequacy; applicable CH TRU operational-testing emplacement and retrieval experience; evaluations of backfill materials' behavior; data on brine and chemical tracer sorption in the backfill materials; and, scientifically defensible information for the WIPP performance assessment modeling studies. Another major objective of this in situ testing was to provide repository relevant guidance plus data for supporting regulatory compliance evaluations, in advocacy of eventual WIPP radioactive waste acceptance and supporting repository operations, to help validate the concept of safe $\mathrm{CH}$ TRU disposal in salt.

These in situ tests involved the emplacement of 174 full-size $(210 \mathrm{~L}) \mathrm{CH}$ TRU waste drums in WIPP underground test Room J, under "materials overtest" environmental conditions, i.e., under slightly elevated temperature and in the presence of a large pool of $\mathrm{NaCl}$ brine, plus the emplacement of another $240 \mathrm{CH}$ TRU waste drums in Room T, under "near-reference" repository 
conditions. Both test rooms were heated and maintained at about $40^{\circ} \mathrm{C}$, about $10-15^{\circ} \mathrm{C}$ higher than mine ambient. The $\mathrm{CH}$ TRU drums, configured in units of six-packs, were enuplaced then partially or totally backfilled with either WIPP crushed salt or a tailored (i.e., brine- and nuclide-sorbing) backfill mixture consisting of $70 \mathrm{wt}$. \% crushed salt and $30 \mathrm{wt}$. \% bentonite clay. The purpose of the brine pool in Room $\mathrm{J}$, also heated to $\sim 40^{\circ} \mathrm{C}$, was to provide an environmental overtest to accelerate corrosion rates in the near-term (several year) time frame, and to provide an indication of the relative behavior properties of the brine-moistened backfill materials, as a function of location in the test room -- relative to the brine pool and the salt walls.

The "materials overtests" conducted in Room J were in heated operation for 3.75 years prior to retrieval. CH TRU drums, backfill material samples, and brine specimens were removed after $0.5,1,1.5,2,2.5$, and 3.75 years for posttest laboratory analyses and interpretations. Tests in Room $\mathrm{T}$ are still in operation, after more than 6 years. This paper focuses on the results obtained from the completed tests in Room J and summarizes: drum corrosion resistance and behavior of protective coatings as a function of time; evaluations of backfill materials applicability as it pertains to brine sorption, crusting and compaction behavior, and impacts on drum retrieval operations; and, measurements of the sorption and migration of emplaced, chemical tracers (actinide and fission product simulants) in the brine-moistened backfill materials. Full background. information and objectives for these experiments, plus pretest technical details on the design, setup, and conduct are documented in a separate Test Plan. ${ }^{2}$

\section{EXPERIMENTAL}

The simulated $\mathrm{CH}$ TRU waste tests were conducted in two separate underground rooms in the WIPP, Room J, for the environmental overtest experiments, and Room T, for the nearreference conditions CH TRU tests. As mined, Room J was $3.7 \times 7.0 \times 29.9 \mathrm{~m}(12 \times 23 \times 98 \mathrm{ft}$, $\mathrm{H} \times \mathrm{W} \times \mathrm{L}$ ) in size; the $174210-\mathrm{L} \mathrm{CH} \mathrm{TRU} \mathrm{test} \mathrm{drums} \mathrm{occupied} \mathrm{the} \mathrm{southernmost} 19.7 \mathrm{~m}$ of this room. A brine pool, from 0 to $0.91 \mathrm{~m}$-deep $(0$ to $3 \mathrm{ft}$.) was mined into the central $11.9 \mathrm{~m}$ of this length. Figure 1 illustrates a section view of the Room J tests and the brine pool. Room $\mathrm{T}$ is 3.96 $\times 10.1 \times 45.7 \mathrm{~m}(13 \times 33 \times 150 \mathrm{ft})$ in size; the 270 drums in this room occupy only $13.4 \mathrm{~m}(44 \mathrm{ft}$.) of its length. Both rooms are located within a relatively thick layer of competent rock salt, about $95 \%$ halite $(\mathrm{NaCl})$, with traces of argilaceous (clay) materials, discontinuous clay partings, and impurities such as anhydrite and polyhalite. The floor of both test rooms is about $654 \mathrm{~m} \mathrm{(2147 \textrm {ft } )}$ below ground level. The $\mathrm{CH}$ TRU drums are surrounded by rigid retaining walls (concrete beams) that serve the function of holding constant the relative positions of the drums during salt (wall) creep, and of holding the backfill materials, surrounding the drums, in place.

The CH TRU drums are 210 L (55 gallon), ASTM 1018 mild steel drums, Department of Transportation specification DOT 17C. These new drums were obtained from the Rocky Flats

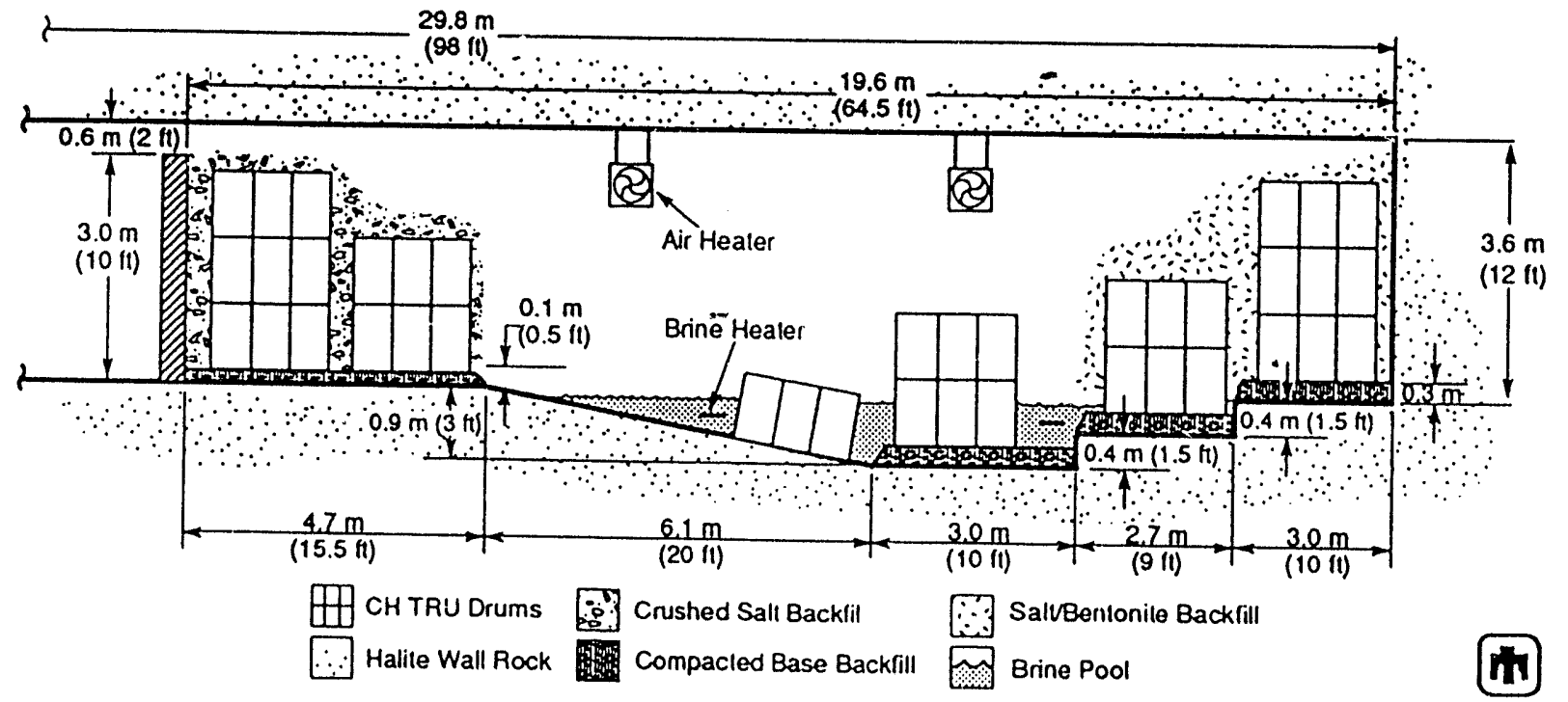

Figure 1. Simulated CH TRU Waste Test in WIPP Room J - Section View 
Plant and are identical to those used for much current $\mathrm{CH}$ TRU waste packaging. Drums are constructed of 16 gage $(1.52 \mathrm{~mm}, 0.060$ in. nominal wall thickness) steel, with an interior clear enamel coating and an exterior coating of white acrylic enamel. They contain a thick polyethylene inner liner and lid, i.e., a corrosion-resistant secondary barrier, but no $\mathrm{CH}$ TRU wastes. Crushed salt fill was used to bring the gross weight of some of these packages up to $150 \mathrm{~kg}$, for purposes of operational handling relevance. The drums were arranged in rectangular "6-packs," and held together with mild steel "angle iron"-type frames that were coated with a thick coal tar epoxy paint. Drums were stacked either one, two, or three layers high, depending on room location; refer to Figure 1. This "6-pack" arrangement, three layers high, was the reference repository emplacement geometry when these tests were proposed and installed. Since that time, however, the reference packaging was clianged to hexagonal "7-packs" of drums held together with a stretchwrapped, plastic-film band. For the materials-related objectives of these tests, the difference between "7-packs" and the earlier "6-packs" is not expected to be significant.

Two types of backfill material were used in these tests: (1) WIPP crushed salt; and, (2) 70 wt. $\%$ crushed salt $/ 30 \mathrm{wt}$. \% bentonite clay. These two types were used in order to determine materials performance (brine and nuclide sorption, compaction behavior, impacts on container corrosion, and effects on emplacement and retrieval operations) relative to each other and to the "air, no-backfill" case. The crushed salt was as-mined, then screened to remove all particles greater than $0.6 \mathrm{~cm}(0.25 \mathrm{in}$.) in size. The clay used was MX-80 granular Volclay bentonite, predominantly a Na- (with $\mathrm{Ca}$-, and $\mathrm{Mg}$-) montmorillonite. The bentonite was blended with crushed salt underground at WIPP. The granular backfill materials were emplaced over the top of concretebeam support walls, onto and between the pre-stacked CH TRU drums, using either an augertype or a conveyor belt-type of apparatus. Both backfill materials had an initial, as-emplaced bulk density of $1.3 \mathrm{~kg} / \mathrm{m}^{3}$. There was also a "base layer" of backfill material emplaced on the floor of the test rooms that was either $15 \mathrm{~cm}$-thick (salt) or $30 \mathrm{~cm}$-thick (salt/bentonite). The "base layer" backfill was installed and tamped or precompacted in-place prior to drum emplacement. The base layer provides both a complete "envelope" of backfill material around the waste containers and a smooth, level floor for emplacement equipment and operations.

In test Room J, we also monitored the in situ migration of chemical species that potentially could be leached from actual TRU wastes. Since no radioactive species were used in these tests, several chemical tracer, nuclide sources were substituted. In order to simulate the sorptive, multivalent chemical species expected from transuranics, we substituted several lanthanide species, Eu, $\mathrm{Sm}$, and $\mathrm{Gd}$, all as trichlorides. We emplaced these chemicals under multiple $\mathrm{CH}$ TRU drums at, or near the top of, the backfill base layer as $5 \mathrm{~cm}$-diameter compressed disks, surrounded by a Teflon holder, so that the disks functioned as (near) "point" sources.

After emplacement of the nuclide sources, drums, and backfill materials, the brine pool was filled with about $1 \times 10^{4} \mathrm{~L}$ of near-saturated $\mathrm{NaCl}$ brine. This brine was prepared by adding excess WIPP crushed salt to (drinking-quality) water in a large open container, stirring, and allowing to equilibrate for about a week. Two other nonradioactive chemical, fission product simulants $\mathrm{Cs}^{+1}$ and $\mathrm{I}^{-1}$ were also dissolved in this brine. Eighteen days after the brine pool was filled, safety and administrative checks were conducted, and the test was officially started when the room air electric heaters were turned-on and the brine pool immersion-heaters activated. Air and brine temperatures were remotely monitored and adjusted appropriately to maintain the desired $\sim 40^{\circ} \mathrm{C}$.

\section{RESULTS AND DISCUSSION}

\section{Backfill Moisture}

Samples of the crushed salt backfill obtained several months to two years after emplacement had moisture contents from 0.10 to $0.24 \%$, as measured by thermal gravimetric analysis. Salt samples that appeared somewhat encrusted (self-standing, near the salt wall interface) or even somewhat damp had moisture levels of 0.15 to $1.4 \%$. The salt/bentonite mixture had an initial moisture value of $\sim 1.7 \%$, primarily because of the propensity of bentonite to sorb moisture. Over time, the salt/bentonite backfill attained moisture levels of between 6.1 to $12.3 \%$, particularly in the vicinity near the brine pool. However, similar salt/bentonite material several meters from the 
brine pool stayed relatively dry, with a measured moisture level ranging from 0.58 to $3.9 \%$, even in the presence of the high humidity in test Room J. (Similar salt/bentonite samples from Room $\mathrm{T}$, without the brine pool, had moisture levels less than $1.8 \%$.) The salt/bentonite backfill material became noticeably encrusted over time because of both moisture (humidity) condensation and wicked-brine sorption near the backfill-salt wall interface, forming a hard, dried crust about 10 to $20 \mathrm{~cm}$-thick. At the time of the test conclusion and drum retrievals, brine wicking-sorption in the immediate vicinity of the brine pool resulted in a damp backfill layer 60 to $100 \mathrm{~cm}$ high. Sorbed moisture held by the salt/bentonite was responsible for significant areas of drum corrosion, as discussed below. Moistened salt/bentonite material had a physical consistency resembling dried mud or crumbly cement. Retrieval of test drums from the moistened backfill required the use of physical labor -- including the use of shovels and in some instances jackhammers to free the drums. Although the crushed salt backfill (further from, and not dipping into the brine pool) had a lower moisture content than the salt/bentonite material, available wicked moisture was adequate to cause some dissolution and recrystallization of the salt. Retrievals of drums from dampened salt was even more laborious than from the salt/bentonite material. Crusting or hardening of either backfill material was significant, increasing the difficulty of drum-retrieval operations near the outer periphery of the backfill stacks, nearest the salt floor and walls.

\section{Corrosion}

Retrieved drum samples were visually inspected, then sectioned and sampled in situ, to remove segments most corroded, prior to laboratory corrosion analyses. Some early samples were cleaned in Clarke's solution, according to ASTM standard G1-81. This procedure removed both the paint and corrosion deposits and allowed our measurement of the nominal metal thickness at several locations. Most later evaluations were qualitative in nature. Observed, predominantly oxic-condition corrosion results ranged from essentially none, to superficial, to severe uniform and localized (crevice and pitting) attack, predominantly depending on exposuie duration and moisture condition. Most of the drums exhibited some degree of time-dependent corrosion. Some were in very good condition even at the end of the test exposure.

Drums in the crushed salt backfill exhibited most corrosion on the drum-rib areas, where paint was mechanically abraded during handling. Some paint blistering was also noted, again mainly on the ribs. Drums on the topmost layer exhibited minimal, superficial rusting. Most drums on the bottom layer had slightly more, but still minimal rib- or bottom-third corrosion, except for three drums with extensive corrosion near the salt wall interface. This observed corrosion is assumed to result from brine wicking from the salt wall, through the backfill.

Drums sitting in the brine pool showed essentially no corrosion below the brine level for the first 12 months. The exterior enamel paint was dissolved off, but the bare metal was shiny. This is indicative of the low oxygen content in the brine. At the conclusion of the test, however, all of these drums exhibited moderate to severe corrosion, particularly at the air-brine interface where there was significant salı crusting and several instances of complete drum perforation. $\mathrm{Crc}$ ice conditions were established in an oxygen concentration cell between the drum and salt-deposit crevice. The coal tar epoxy paint on mild steel, 6-pack frames effectively prevented any noticeable corrosion, even after 3.75 years of warm brine exposure.

Drums sitting in humid air, on a second level above the brine pool had only slight surface rusting even after 3.75 years, primarily on rib areas where paint had been abraded. However, other drums sitting in humid air at the back of the test room had some water (from humidity) condense on them. These drums were heavily crusted with top-surface corrosion products and had some moderate bottom- and rib-area corrosion, with pitting observed on the ribs.

The extent of corrosion on drums surrounded by salt/bentonite backfill was quite dependent on room position and backfill moisture content. Drums on the middle or top layer, in relatively dry backfill, had minimal surface rusting and minor paint blistering on the ribs -- except for a few drums that were located at the top, at the salt wall interface. This observed corrosion is assumed to result from brine wicking from the salt wall and/or from moisture condensation, migrating through the salt/bentonite backfill, and held in contact with drum surfaces. Drums on the bottom layer in contact with damp backfill, particularly those nearest the brine pool, suffered severe corrosion on the bottom $1 / 2$ to $2 / 3$ of their height, and many had extensive perforations. The 
bentonite sorbs more brine than the crushed salt, holds it in contact with the surface of the drums, and provides a more favorable condition for steel crevice corrosion to occur. Multiple pitting holes occurred on the drum-rib area where brine-moistened backfill material clung. Analyses of rust deposits showed a mixture of oxides and chlorides. There was evidence of several iron compounds including hematite, magnetite and various hydrous iron oxy-chlorides.

Because of the presence of the brine pool and increased tempcrature in Room J, observed corrosion results must be considered to be from severe overtest conditions, and not repository relevant. Corrosion results ${ }^{1,2}$ from Room $\mathrm{T}$ are much more representative of those to be expected in the actual TRU waste storage and isolation rooms at WIPP. Room T drum analyses, through 30 months of observation, indicated only superficial rusting, primarily on drum ribs with abraded paint. $\mathrm{CH}$ TRU waste drums should retain more than adequate mechanical integrity to allow retrievability, if required for any purpose, for at least five years. The thick polyethylene liner and lid inside each drum also provides another layer of near-term, physical barrier integrity.

\section{Tracer Migration}

The $\mathrm{Cs}^{+1}$ and $\mathrm{I}^{-1}$ concentrations in the brine pool and in the adjacent backfill materials were monitored periodically. The initial $\mathrm{Cs}^{+1}$ concentration in the brine pool, analyzed by instrumental neutron activation was $75 \mathrm{ppm}$. This increased about $40 \%$, to $110 \mathrm{ppm}$ over the next 4.5 months, as water in the brine pool evaporated in the warm test room. Similarly, the initial $\mathrm{I}^{-1}$ concentration, measured by specific ion electrode, changed from $195 \mathrm{ppm}$ initially to $277 \mathrm{ppm}$ after 4.5 months. The brine pool was periodically replenished with fresh water to prevent it from drying out. The maximum $\mathrm{Cs}^{+1}$ concentration found in crushed salt backfill material, about $30 \mathrm{~cm}$ from the brine pool, was only $2.7 \mathrm{ppm}$; it was only $0.24 \mathrm{ppm}$ in crushed salt/bentonite backfill about $90 \mathrm{~cm}$ from the brine pool. Maximum $\mathrm{I}^{-1}$ concentrations were $3.9 \mathrm{ppm}$ in crushed salt material and $5.9 \mathrm{ppm}$ in crushed salt/bentonite backfill. Neither element is being selectively sorbed in significant quantity by the backfills. However, there is evidence of some preferential $\mathrm{Cs}^{+1}$ sorption from the brine that had migrated $<1 \mathrm{~m}$ through the bentonite-containing backfill.

None of the lanthanide species, $\mathrm{Eu}, \mathrm{Sm}$, and $\mathrm{Gd}$, (as well as $\mathrm{La}, \mathrm{Yb}$, and $\mathrm{Nd}$; and multivalent heavy metals $\mathrm{Hf}^{+4}, \mathrm{Ta}^{+5}, \mathrm{Sb}^{+3}$, and $\mathrm{Sb}^{+5}$, also emplaced) were detectable in the brine pool after 4.5 months. We used instrumental neutron activation analysis, with a detection sensitivity of 0.05 $\mathrm{ppm}$. This sensitivity would have been adequate for detection if more than $0.3 \%$ of the chemical species were present.

When we concluded this test was -1fter 3.75 years, the backfill materials and test drums were removed and sampled, exposing the nuclide-source disks. To obtain an indication of nuclide migration away from the emplacement sites, we took core samples at various distances avvay from the sources. The posttest samples consisted of $2.5 \mathrm{~cm}$-diameter cores obtained by driving steel pipes into the largely consolidated, base-backfill material. The depth of the cores was up to 30 $\mathrm{cm}$. We cut each core sample into $2.5 \mathrm{~cm}$-long segments for analyses, by direct coupled plasma spectroscopy. The $\mathrm{Eu}^{+3}$ source was emplaced on compacted crushed salt/bentonite backfill at a level slightly above the top of, and about $20 \mathrm{~cm}$ from the brine pool. The backfill base material was, however, damp. The maximum $\mathrm{Eu}^{+3}$ concentration found in the bulk core material sample was $5400 \mathrm{ppm}$ on the surface of the backfill, at a distance of $7.6 \mathrm{~cm}$ from the source. This concentration decreased to $100-200 \mathrm{ppm}$ at the same location, but 1.5 to $7.6 \mathrm{~cm}$ down, and only 1 $\mathrm{ppm}$ at $10 \mathrm{~cm}$ down. No $\mathrm{Eu}^{+3}$ was detected over about $0.6 \mathrm{ppm}$ at any further distance horizontally or vertically. Migration of the $\mathrm{Eu}^{+3}$ appears to be quite restricted. This may be a function of the relative lack of free fluid movement, with $\mathrm{Eu}^{+3}$ sorption on bentonite, and assuming that diffusion is the dominant process.

In contrast to the behavior of $\mathrm{Eu}^{+3}$, both $\mathrm{Sm}^{+3}$ and $\mathrm{Gd}^{+3}$ were found widely distributed at distances up to $60 \mathrm{~cm}$ from the sources and at depths up to about $25 \mathrm{~cm}$. Both the $\mathrm{Sm}^{+3}$ and $\mathrm{Gd}^{+3}$ sources were emplaced on the compacted crushed salt/bentonite base backfill, in the center of the brine pool, below the brine level, but covered over by a drum. The $\mathrm{Gd}^{+3}$ concentration was fairly constant at about $20-100 \mathrm{ppm}$ at distances of about 8 to $60 \mathrm{~cm}$ horizontally and 0 to $25 \mathrm{~cm}$ down. $\mathrm{Sm}^{+3}$ concentrations were similarly distributed but were a little higher in magnitude. Both $\mathrm{Sm}^{+3}$ and $\mathrm{Gd}^{+3}$ exhibited a significant peak in concentrations ( 1000 to $\left.3000 \mathrm{ppm}\right)$ at a depth of about 12 to $17 \mathrm{~cm}$, at a horizontal distance of about $8 \mathrm{~cm}$ from the sources. This concentration 
fell rapidly as a function of radial distance. None of these observations can be explained by simple diffusion. It is likely that these features represent the mass transport of the brine within the pore space of the backfill material. Where there was abundant brine, the tracers became widely dispersed. Bentonite in this case appears not to be a wholly effective scavenger for these elements.

\section{CONCLUSIONS}

We have conducted multi-year tests of the materials behavior of nonradioactive waste containers and backfill materials under various environmental conditions in the WIPP facility. We comparatively evaluated the effects of crushed salt and salt/bentonite backfills on container durability and fluid and nuclide sorption. Brine migration from the "overtest" brine pool in Room $\mathrm{J}$, and potential naturally occurring brine from brine seeps in the salt walls and floor, through the backfill, can have a significant impact for "cementing" the backfill materials. This brine-wicking can make drum retrieval activities more difficult. The salt/bentonite backfill more effectively sorbed moisture (and transuranic and fission-product chemical simulants) than did the crushed salt. Crushed salt, however, tends to reconsolidate more when moistened. Any brine present will be effectively sorbed by the backfill, significantly hindering further liquid transport, so that transport of potentially leached-waste radionuclides is significantly minimized. However, backfill moisture sorption holds the corrodant against adjacent drum surfaces, enhancing drum corrosion.

Actual CH TRU waste drums surrounded by "dry" granular backfill materials (without a brine pool!) should experience only superficial external corrosion for' douut. rne tirst several years after emplacement in the WIPP. Limited drum corrosion data frcm Room $T$ testing supports this statement. Overtest drum corrosion data from Room $\mathrm{J}$ indicates that appreciable general corrosion and pitting can occur under brine-moistened backfill conditions, due chiefly to crevice corrosion. While useful for evaluating eventual failure mechanisms, this Room $\mathrm{J}$ data should be considered as supplemental, and not be viewed as fully applicable to anticipated environmental conditions in the WIPP. If potential brine intrusion and sorption on the backfill material occurs in the long-term (post-repository operations phase), corrosion of the mild steel drums will certainly occur. Moisture contact with the $\mathrm{CH}$ TRU waste materials (and subsequent waste leaching) can occur only after the drums, as well as the internal polyethylene drum liners, are eventually breached, either by corrosion or mechanical crushing pressures. The waste drums were never intended to be a long-term corrosion or physical barrier.

We are still obtaining further materials-related information in the parallel, continuing test in Room $\mathrm{T}$, without a brine pool. We consider future termination and retrieval activities from Room $\mathrm{T}$ to be important, directly relevant WIPP activities, needed to provide non-overtest information on longer-term waste package integrity and backfill behavior. This non-overtest information (on brine-wicking and consequent cementing of backfills, drum corrosion, potential drum deformation due to salt wall creep, and any potential operational or safety impacts) would be extremely useful for adequately demonstrating to WIPP regulatory and review groups that backfilled drums could be retrieved successfully and safely, even after many years of emplacement.

\section{REFERENCES}

1. Molecke, M.A. 1986. TEST PLAN: WIPP Simulated CH and RH TRU Waste Tests: Teshnology Experiments (TRU TE). Albuquerque, NM: Sandia National Laboratories.

2. Tyler, L.D., R.V. Matalucci, M.A. Molecke, D.E. Munson, E.J. Nowak, and J.C. Stormont. 1988. Summary Report for the WIPP Technology Development Program for Isolation of Radioactive Waste. SAND88-0844. Albuquerque, NM: Sandia National Laboratories.

3. Molecke, M.A. 1993. "Results from Simulated Remote-Handled Transuranic Waste Experiments at the Waste Isolation Pilot Plant (WIPP)," Scientific Basis for Nuclear Waste Management XVI. Eds. C.G. Interrante and R.T. Pabalan. Pittsburgh, PA: Materials Research Society. Vol. 294, 481-486. 


\section{DISCLAIMER}

This report was prepared as an account of work sponsored by an agency of the United States Government. Neither the United States Government nor any agency thereof, nor any of their employees, makes any warranty, express or implied, or assumes any legal liability or responsibility for the accuracy, completeness, or usefulness of any information, apparatus, product, or process disclosed, or represents that its use would not infringe privately owned rights. Reference herein to any specific commercial product, process, or service by trade name, trademark, manufacturer, or otherwise does not necessarily constitute or imply its endorsement, recommendatior, or favoring by the United States Government or any agency thereof. The vi :ws and opinions of authors expressed herein do not necessarily state or reflect those of the United States Government or any agency thereof. 
$-\cdots$
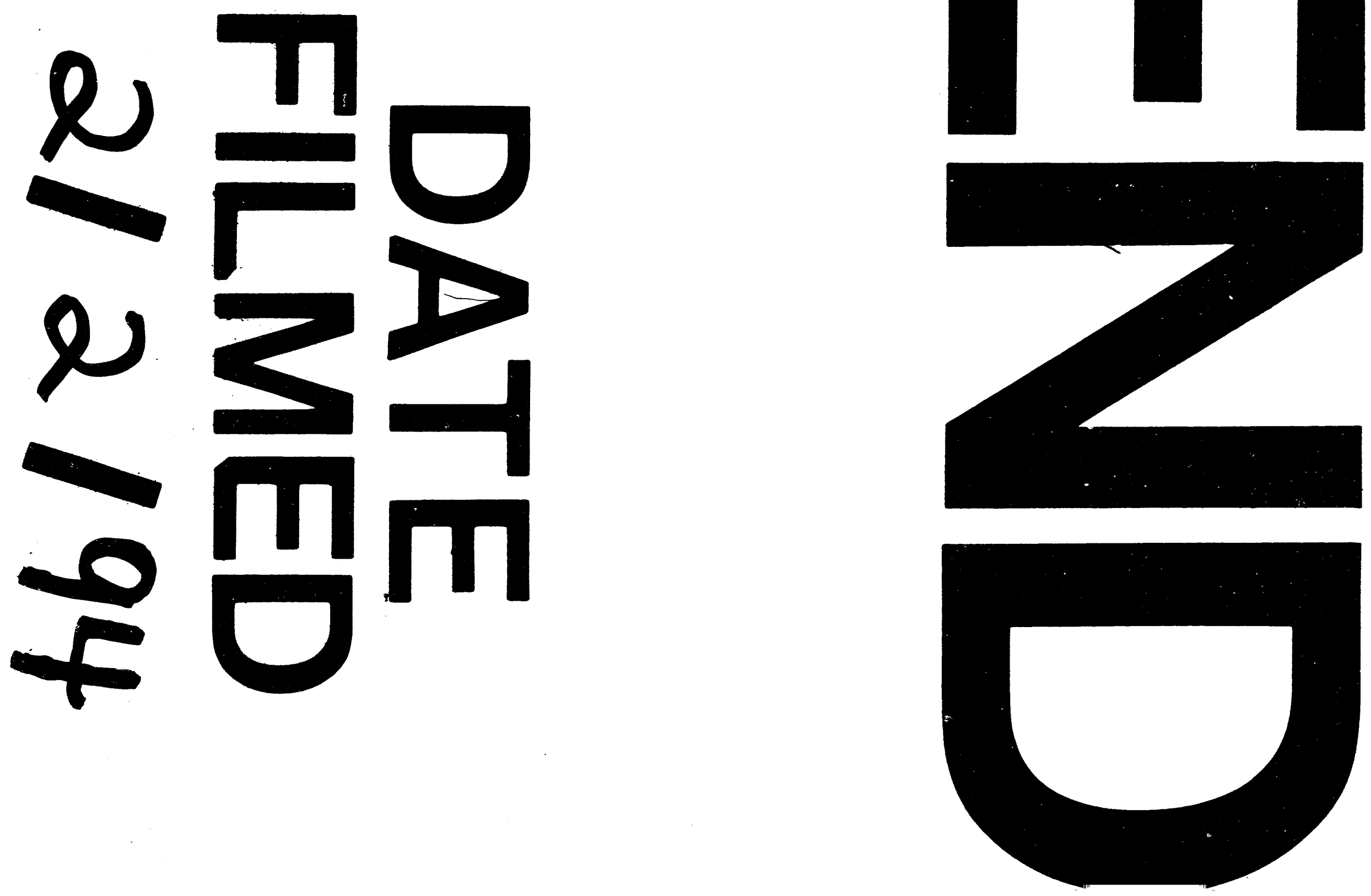


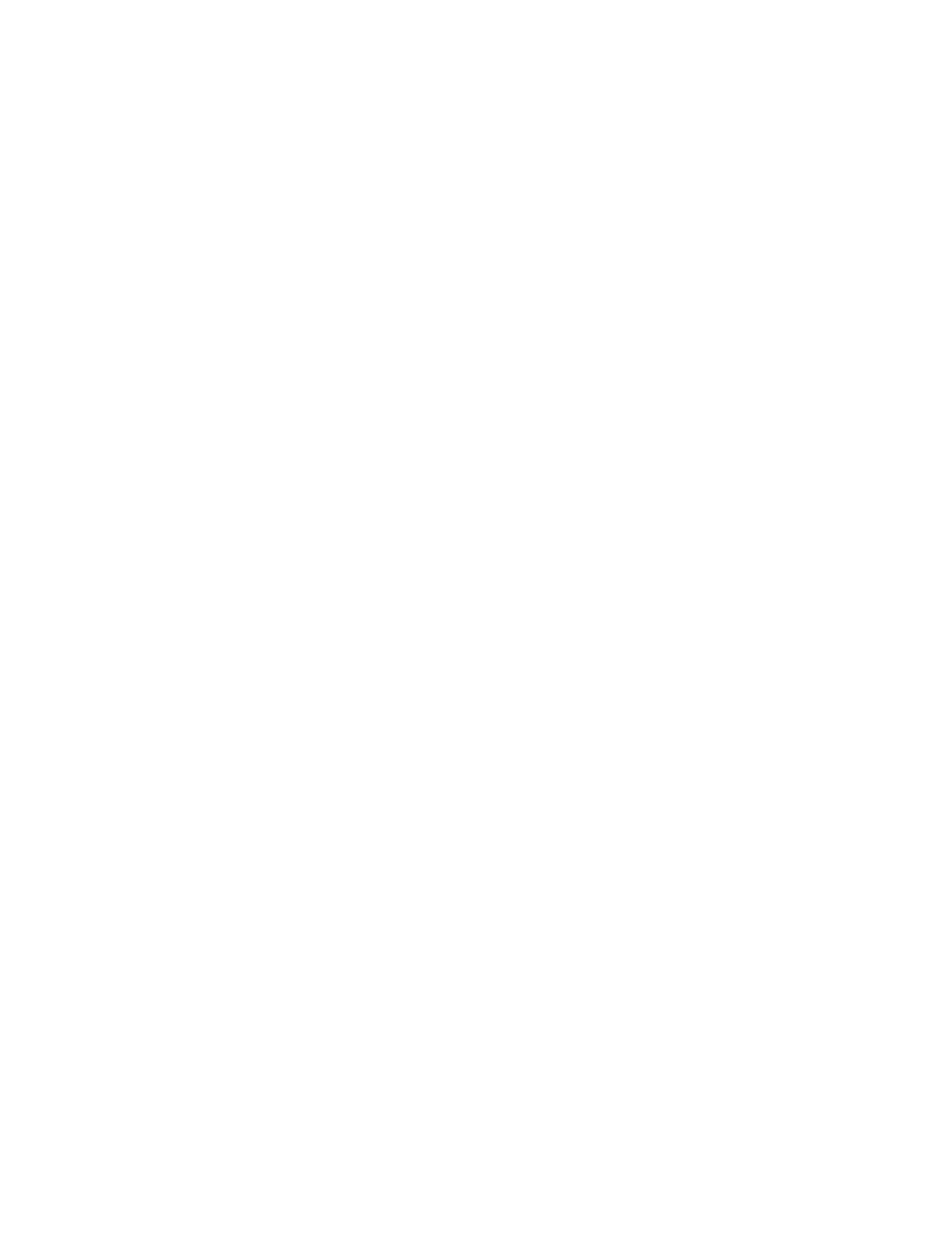

